TILTAI, 2016, 1, 15-37, ISSN 1392-3137 (Print), ISSN 2351-6569 (Online)

\title{
SKUBI MEDICINOS PAGALBA: TARPHOSPITALINIAI PERVEŽIMAI
}

\author{
Gintautas Virketis, Vinsas Janušonis, Vita Kvekšaitė \\ Klaipédos universitetas, Klaipédos universitetiné ligoniné
}

\begin{abstract}
Anotacija
Straipsnyje analizuojama pacientų, kuriems reikia skubios medicinos pagalbos, tarphospitalinių pervežimų problema Lietuvoje vykdomo sveikatos priežiūros įstaigų ir paslaugų restruktūrizavimo, stacionarinių paslaugų centralizavimo ir regionalizavimo politikos kontekste. Nors deklaruojami restruktūrizavimo tikslai - paslaugų prieinamumas ir kokybès gerinimas, paslaugų teikimo netolygumų ir socialinès atskirties mažinimas, tačiau padidèjęs tarphospitalinių pervežimų skaičius ir skubios pagalbos prièmimo skyrių pacientų srautų pokyčiai rodo galimas neigiamas tendencijas. Vienas esminių pacientų transportavimo reikalavimų - nenutrūkstamas skubios pagalbos paslaugų teikimas transportuojant. Straipsnyje pateikiama vieninga tarphospitalinių pervežimų samprata, atlikto greitosios medicinos pagalbos ir stacionarinių įstaigų vadovų bei specialistų nuomonių tyrimo rezultatai apie esamą tarphospitalinių pacientų srautų valdymo situaciją ir būdus, kaip būtų galima tobulinti pacientų srautų valdymą. Tyrimas atliktas anketinès apklausos metodu, sugrupavus klausimus pagal tyrimo siekinius į atskiras grupes. Tyrimo rezultatų pagrindu pateiktos motyvuotos išvados ir sukurta skubios medicinos pagalbos pacientų srautų schema.

PAGRINDINIAI ŽODŽIAI: skubi medicinos pagalba, pacientų srautai, valdymas, paslaugų restruktūrizavimas, tarphospitalinis pervežimas, regionalizavimas.
\end{abstract}

\begin{abstract}
In this article an emergency medical assistance and the inter hospital transfer problems are analysed in context of the restructurization of health care institutions and services, also of regionalization and centralization policy in Lithuania. Though the increased accessibility of health care services and improvement of the quality, also reduction of social exclusion and unevenness of provision of health care services are declared as the main objectives (purpose) of restructurization, however increased number of inter hospital transfers and crowding of the Emergency Departments indicate the possible negative tendencies. One of the substantial (fundamental) requirement of the inter hospital transfers is the continuous emergency care during transportation. The article provides a unified concept of second transportation between hospitals. The survey results contain the points of specialists and executives of emergency medical assistance on the current management situation of inter hospital patient flow and the ways how the management of patient flow can be improved. The study was made using questionnaire survey, the questions were divided into separate groups by the objectives of this study. Reasoned conclusions and the scheme of the emergency medical care patients flow are developed with reference to the results of this study.
\end{abstract}

KEY WORDS: an emergency medical assistance, flow of the patients, management, restructurization of health care services, inter hospital transfer (transportation), regionalization.

DOI: http://dx.doi.org/10.15181/tbb.v73i1.1263 


\section{Ivadas}

Pastaruoju metu užsienio šalių mokslininkų straipsniuose dėmesys kreipiamas ị tarphospitalinių pacientų srautų didèjimą. Jungtinèje Karalystèje kasmet tarp ligoninių pervežama daugiau nei 11000 kritinès būklès, sunkiai sužeistų pacientų (Gray et al., 2004, p. 281; Fried et al., 2010, p. 136-144). Olandijoje pradejus regionalizacijos politiką ir iškejlus intensyvios pagalbos centrus ị didesnes ligonines, išaugo tarphospitalinių pervežimų skaičius (Lieshout et al., 2008, p. 269). Australijoje 2002-2006 m. vidutiniškai apie 14,2 \% per metus didẻja pervežimų tarp ligoninių skaičius (Gillman et al., 2013, p. 149).

Dèl Lietuvoje vykdomo sveikatos priežiūros įstaigų ir paslaugų restruktūrizavimo ir vis labiau centralizuojamų stacionarinių paslaugų keičiasi transportuojamų ir savarankiškai ị Prièmimo skubios pagalbos skyrius (toliau - Prièmimo skyrius) atvykstančių pacientų srautai. Asmens sveikatos priežiūros ịstaigų (toliau - ligoninès) prièmimo skyriuose neplanuotai ir nevaldomai išaugę pacientų srautai gali iš esmès pabloginti tose ligoninėse teikiamų asmens sveikatos priežiūros paslaugų kokybę, nors deklaruojami restruktūrizavimo tikslai - paslaugų prieinamumas ir kokybės gerinimas. Daugelyje ligoninių, uždarius skubią medicinos pagalbą teikiančius skyrius (prièmimo, reanimacijos, chirurginio profilio), skubi medicinos pagalba pacientams gali tapti sunkiau prieinama arba suteikta nekokybiškai ir ne laiku (10-ies rajonų ligoninių chirurgijos skyriai uždaryti po trečio restruktūrizacijos etapo). Nors pacientų srautai iš tokių ligoninių, siekiant suteikti skubią medicinos pagalbą, bus nukreipti ị universitetų ar didžiųjų miestų ligonines, apie kokybišką pacientų transportavimą i šias ịstaigas ir atgal dar diskutuojama.

Lietuvoje, vykdant stacionarinių paslaugų centralizavimo ir regionalizavimo politiką, transportuojamų pacientų srautai taip pat didejja. Nuo 2010 m. ypač padaugejo Greitosios medicinos pagalbos (GMP) ị ligonines vežamų pacientų skaičius. Per 2000-2014 m. laikotarpi i ligonines GMP atvežamų pacientų skaičius išaugo 1,43 karto (iš 2000-2014 metų GMP ataskaitos). Tai susiję su $2010 \mathrm{~m}$. Sveikatos apsaugos ministerijos (SAM) priimtu įsakymu, kuris reglamentuoja pacientu siuntimą ị atitinkamo lygmens asmens sveikatos priežiūros ịstaigas (Žin., 2010, Nr. 21-1010), ir trečiuoju gydymo įstaigų bei paslaugų restruktūrizavimo etapu (Žin., 2009, Nr. 150-6713). Ligonio pervežimo paslauga greitosios medicinos pagalbos paslaugų struktūroje užima trečią vietą ir jos teikimo mastai nuolat didejja nuo 8,6 \% $2001 \mathrm{~m}$. iki 11,6 \% $2014 \mathrm{~m}$. Duomenys, kokią dali iš GMP transportuojamų pacientų sudaro iš įvykio vietos vežami pacientai, o kokią - iš ligoninès ị ligoninę, nepateikiami. Apie tarphospitalinès pagalbos apimtis ir transportavimo poreiki iš dalies galima spręsti remiantis Skubios konsultacinès pagalbos (SKP) ir Specializuotos skubios konsultacinès pagalbos (SSKP) veiklos rodikliais. Ly- 
ginant 2009-2013 m. rodiklius ir apimtis matyti, kad per 5 metus tarphospitalinių pervežimų daugejjo tik šiek tiek, tačiau vertinant atskirai 2009 m. ir 2013 m., $2013 \mathrm{~m}$. transportuota 631 (17\%) ligoniu daugiau nei $2009 \mathrm{~m}$. (Valstybinè ligonių kasa, 2014). Tarphospitalinių pacientų transportavimo duomenys esamuose klasteriuose viešai nepateikiami, todèl šiu duomenų trūkumas neleidžia atlikti detalesnès tarphospitalinių pacientų srautų analizès. Pacientai klasteriuose dažniausiai transportuojami GMP brigadų ir SKP tarnybų, bet neretai ir pačių gydymo ịstaigų automobiliais, esant minimaliai paciento stebèsenai ir pagalbos teikimo galimybei transportuojant.

Akivaizdu, kad tarphospitaliniai pervežimai didina žmogiškujų išteklių, techninès įrangos, pervežimo sistemų, regioninių ir tretinių sveikatos priežiūros centrų išteklių poreikị, todėl įvairių tokių pervežimų aspektų analizė yra svarbi, siekiant veiksmingai planuoti šį procesą (Rourke, Kennard, 2001, p. 297).

Prioritetinèse restruktūrizavimo kryptyse siūlomi šie modeliai: atsisakyti specializuotų sveikatos priežiūros paslaugų teikimo, pacientus nukreipiant ị aukštesnio lygio ligonines ar specializuotas paslaugas teikti kraštų ir apskričių centrų šias paslaugas teikiančiose ligoninèse. Daugelis Lietuvos ligoninių vadovų turi spręsti problemas, kurios susijusios su pacientų transportavimu, netekus teisės teikti skubių ir specializuotų paslaugų. Deja, Lietuvoje, vykdant sveikatos priežiūros restruktūrizavimą, tarphospitalinio transportavimo problema bendrame paslaugų optimizavimo kontekste nesprendžiama.

Siekiant atlikti išsamesnę tarphospitalinių pervežimų problemų ir priimamų sprendimų analizę, būtina vieninga diskutuojamo dalyko samprata. Moksliniuose straipsniuose pateikiami tokie pacientų transportavimo terminai: „Pirminis paciento transportavimas - iš įvykio vietos ị gydymo įstaigą. Antrinis, kitaip dar vadinamas tarphospitalinis, transportavimas - iš vienos gydymo ịstaigos ị kitą, tęsiant paciento gydymą" (Gray et al., 2004, p. 281). Australijos tarphospitalinių pervežimų gairėse pateiktas toks apibrèžimas: „Tarphospitalinis pervežimas yra bet koks paciento pervežimas iš vienos ligoninès tiesiai į kitą, patarus medicininiam personalui, nepaisant to, prièmè kita ligoninè ar ne“ (Zanco, 2014, p. 1). Deja, ši samprata tinka tik tarphospitaliniam pervežimui, kai pacientas vežamas i aukštesnio lygio paslaugas teikiančias ligonines, kai dèl įvairių priežasčiu jų negali suteikti arčiausiai paciento gyvenamos vietos esanti ligoninè. Todẻl straipsnio autoriai siūlo tokị tretinio pacientu transportavimo apibrèžimą: tai atgalinis paciento transportavimas, kai iš aukštesnio lygio ar specializuotas paslaugas teikiančios ligoninès, suteikus reikiamas atitinkamo lygio paslaugas, pagal nustatytą tvarką (pvz., sudarytas sutartis) pacientas pervežamas ị žemesnio lygio ar ị arčiausią ligoninę pagal paciento gyvenamą vietą. Toliau šiame darbe vadovausimès šiomis pirminio, antrinio ir tretinio tarphospitalinio pervežimo sampratomis. 
Tyrimo tikslas: išsiaiškinti ir įvertinti greitosios medicinos pagalbos ir stacionarinių sveikatos priežiūros ịstaigų vadovų bei specialistų nuomones apie esamą tarphospitalinių pacientų srautų valdymo situaciją ir būdus, kaip tobulinti pacientų srautų valdymą.

\section{Tyrimo metodai ir medžiaga}

Atliekant tyrimą taikyta sisteminė mokslinès literatūros analizè, Lietuvos, kitų šalių ir tarptautinių sveikatos organizacijų parengtų sveikatos priežiūros sistemų ataskaitų analizè, sintezè ir apibendrinimas. Atliktas kiekybinis tyrimas anketinės apklausos metodu, duomenų statistinè analizè, teorinis apibendrinimas, modeliavimas. Anketos sudarytos vieno iš autorių (G. Virkečio). Anketa sudaryta autorių B. I. Lidal, H. H. Hilde, E. V. Gunn, remiantis A. Sayah, L. Rogers, K. Devarajan, L. Kingsley-Rocker, L. F. Lobon, N. R. Hoot, D. Aronsky publikacijomis. Respondentais pasirinkti stacionarinių asmens sveikatos priežiūros įstaigų ir greitosios medicinos pagalbos ịstaigų vadovai, reanimacijos ir intensyvios terapijos skyrių vadovai / vedèjai bei prièmimo skubios pagalbos skyrių vedèjai. Kad būtų galima padaryti statistiškai reikšmingas išvadas, tiriamujų imtis turèjo būti 117 ar daugiau asmenų. Anketas tinkamai užpildẻ 118 respondentų.

Anketų duomenų analizei naudota SPSS 21 programa. Statistinejje analizėje ryšiai tarp požymių vertinti chi kvadrato $\left(\chi^{2}\right)$ kriterijumi, 95 proc. pasikliautinujų intervalų, vidurkių lyginimo statistiniais metodais. Statistiškai reikšmingam rezultatų skirtumui ịvertinti pasirinktas $p<0,05$, statistiškai labai reikšmingam $p<0,01$ lygmuo. Anketų atsakymų variantai Nr. 6, atitinkantys reikšmę nežinau, interpretuoti kaip neatsakyta ị klausimą, siekiant apskaičiuoti vertinimų vidurkius pagal 5 balų sistemą, kur 1 atitinka priešingą reikšmę balui 5 . Anketų klausimai, atsižvelgiant ị tyrimo tikslus, sugrupuoti ị atskiras grupes. Pirma klausimų grupe siekiama nustatyti esamą situaciją, klausimai skirti tik GMP vadovams. Antra klausimų grupe siekiama išsiaiškinti, ką ligoninių vadovai ir specialistai mano apie pacientų srautų optimizavimo būdus ir priemones. Trečia klausimų grupė skirta GMP ir ligoninių vadovams bei specialistams, siekiant nustatyti, kaip būtų galima patobulinti skubios medicinos pagalbos srautų valdymą.

\section{Tyrimo rezultatai ir aptarimas}

\subsection{Skubios medicinos pagalbos tarphospitalinių pacientų srautų valdymo teorinès įžvalgos}

Mokslininkai, atsižvelgdami ị pasikartojimų dažnumą ir svarbą, ịvardija šias tarphospitalinių pervežimų problemas: personalo stoka, pervežimo laiko, komuni- 
kacijos trūkumas, mirtingumo pervežant, greitosios medicinos pagalbos automobilio ir stebėsenos problemos (Oakley, 1999, p. 69; Faheem, 2003, p. 18; Iwashyna, 2012, p. 2471).

Tyrime skiriamos kelios aptariamų problemų grupės: sprendimo dẻl pervežimo prièmimo delsimas ir ilgas transportavimo laikas; pacientų srautų nukreipimas; tarphospitalinių pervežimų nuostatai, algoritmai ar rekomendacijos; transportavime dalyvaujančio personalo, transportavimo komandos kvalifikacija; transportavimo būdai ir paciento stebėsena transportuojant; neigiami transportavimo rezultatai, išeitys.

Sprendimo dèl pervežimo prièmimo delsimas ir ilgas transportavimo laikas. Dažnai delsiama priimti sprendimą pervežti pacientą, taip pat ir derinant hospitalizavimą su priimančia ligonine (Wong, Levy, 2005, p. 291; Iwashyna, 2012, p. 2470). Nustatyta, kad siekiant suorganizuoti pervežimą reikia daug kartų skambinti telefonu (vidutiniškai 4,7 skambučio), idealiu atveju turètų užtekti vieno (Craig, 2005, p. 126). Pagrindinès delsimo priežastys: komunikavimo problemos su priimančiomis tretinio lygio paslaugas teikiančiomis ligoninèmis, sunkumai organizuojant transportą ar nedokumentuotos siunčiančioje įstaigoje atliktos intervencijos (Wong, Levy, 2005, p. 291). Pacientų pervežimo proceso atidèliojamą irodo faktas, kad pacientai iš rajoninès ligoninès buvo sunkesnès būklès negu panašūs pacientai, kurie iškart pateko ị tretinio lygio ịstaigas (nors tretinio lygio ligoninès daugiausia gydo sunkiausius ligonius) (Santry, Velmahos, 2012, p. 2945).

Transportavimo trukmé vertinama kaip per ilga ir nurodomas transportavimo laiko vidurkis - 5-10 valandų (Faheem, 2003, p. 7; Wong, Levy, 2005, p. 290; Craig, 2005, p. 126). P. Schoetther ir kt. (2003, p. 188-189) savo analizejje skiria tris transportavimo laiko intervalus: ikihospitalinis laikas (nuo GMP iškvietimo iki patekimo ị ligoninę), hospitalinis laikas (nuo patekimo ị ligoninę iki tarphospitalinio transportavimo), pervežimo laikas (nuo išvežimo iš siunčiančios ligoninès momento iki patekimo ị aukštesnio lygio gydymo ịstaigą). Autorius nurodo, kad hospitalinis laikas $-343 \pm 310 \mathrm{~min}$., tarphospitalinio transportavimo organizavimo vidutinis laikas - $112 \pm 80$ min., laikas iki aukštesnio lygio pagalbos suteikimo $443 \pm 322 \mathrm{~min}$.

Pateiktas transportavimo trukmes palyginome su Klaipėdos universitetinès ligoninès, teikiančios skubios konsultacinès pagalbos paslaugas sveikatos apsaugos ministro (Žin., 2008, Nr. 33-1190) nustatyta tvarka, vidutiniu paciento transportavimo laiku. Šị laiką sudaro: laikas nuo iškvietimo gavimo iki išvykimo ị kviečiančią ligoninę; laikas, sugaištas kelionei iki ir grižimui iš kviečiančios ligoninès (paprastai jis yra trumpesnis, nei vykstant ịprastu automobiliu kelių eismo taisyklèse leistinu greičiu); laikas, sugaištas konsultacijai, dokumentų pildymui, prireikus - procedūrų atlikimui, paciento paruošimui transportuoti. Visų Klaipėdos 
universitetinės ligoninės skubios konsultacinès pagalbos tarnybų vidutinis paciento transportavimo laikas 2014 ir $2015 \mathrm{~m}$. buvo $174 \mathrm{~min}$. Anesteziologų reanimatologu vidutinis paciento transportavimo laikas - $162 \mathrm{~min}$. (2014 m.) ir $102 \mathrm{~min}$. (2015 m.). Neonatalogų vidutinis paciento transportavimo laikas - atitinkamai 336 min. ir $402 \mathrm{~min}$. Anesteziologų reanimatologų ir neonatologų vidutinis paciento transportavimo laikas kartu - 264 min. ir 222 min. Kitų konsultantų vidutinis vienos konsultacijos laikas - 60 min. Daugiausia laiko sugaištama transportuojant naujagimius ir trauminius pacientus. Mūsų nuomone, galima sutrumpinti paciento transportavimo laiką patvirtinus maksimalų laiką, per kurị konsultantai po iškvietimo registravimo turi išvykti ị kviečiančią ligoninę. Pavyzdžiui, Klaipėdos universitetinejje ligonineje (KUL) vyriausiojo gydytojo įsakymu SKP brigados po iškvietimo registravimo turi išvykti per 1 val. (KUL, 2010 m. įsakymas Nr. 98, p. 11).

Didžioji dalis (73 \%) pervežamų pacientų tretinio lygio paslaugas teikiančias ìstaigas pasiekia pasibaigus darbo valandoms. Nustatyta, kad po operacijų, kurios atliekamos ne ịprastomis darbo valandomis, mirtingumas didesnis (Wong, Levy, 2005, p. 290). Kadangi Lietuvoje tokio pobūdžio duomenys nekaupiami, nèra galimybès jų palyginti.

Pacientų srautų nukreipimas. Siekiant veiksmingai planuoti ir organizuoti ligoninių darbą, svarbu nustatyti, kur prireikus turi būti transportuojamas pacientas, jei arčiausiai esanti ligoninė negali suteikti reikiamos pagalbos. Pvz., Anglijos Karališkasis chirurgų koledžas ir Britu ortopedų asociacija rekomenduoja nukentejusijji iš ívykio vietos vežti tiesiai ị tinkamiausio profilio gydymo įstaigą, o ne ị arčiausiai esančią. Jų manymu, tai turètų sumažinti antrinių pervežimų skaičių, ypač transportuojant pacientus su galvos traumomis (Gray et al., 2004, p. 283). Kiti autoriai (Warren et al., 2004, p. 259) pataria ịvertinti tai, kad pacientas iš stacionarinio vieneto (pvz., intensyvios terapijos skyriaus) bus pervežtas ị ambulatorinị (skubios pagalbos skyrių), todèl sunkų pacientą priimanti įstaiga turi būti tam atitinkamai pasiruošusi. Aiškios ar bent preliminarios paciento stacionarizavimo vietos numatymas leistų tiksliau planuoti stacionaro lovų užimtumą.

Tarphospitalinių pervežimų nuostatai, algoritmai ar rekomendacijos. Didejjant traphospitalinių pervežimų poreikiui, atsiranda būtinybẻ ši procesą kontroliuoti, apibrēžiant pervežimų normas, standartus ir pan. Moksliniuose straipsniuose pateikiami tarphospitalinių pervežimų nuostatai arba pervežimo algoritmai, pavyzdžiui, nacionalinis ankstyvas gyvybinių parametrų vertinimo punktų sąrašas, palengvinantis trauminio paciento pervežimą tarp ligoninių. Pateikiamos ir galimos pervežimų (Warren et al., 2004, p. 258), tinkamo tarphospitalinio pacientų transportavimo (Amerikos skubios pagalbos gydytojų kolegija, 2009), Australijos tarphospitalinių pervežimų (Zanco, 2014) gairès. JAV tarphospitalinių pervežimų nuostatai rekomenduoja užtikrinti, kad visi tarphospitaliniai 
pervežimai atitiktų teisinius reikalavimus. I nuostatus įtraukta pirminio paciento vertinimo, stabilizavimo, informuoto paciento sutikimo, atskleidžiančio transportavimo riziką ir naudą, medicininių indikacijų transportuoti, siunčiančio ir priimančio gydytojo bendravimo dokumentacija (Warren et al., 2004, p. 261; Amerikos skubios pagalbos gydytojų kolegija, 2007, p. 7; Chatwin et al., 2011, p. 9). Ir kitose šalyse yra priimtų ir taikomų tarphospitalinių pervežimų algoritmų: Didžiosios Britanijos ir Airijos anesteziologų asociacijos sukurtos tarphospitalinių pervežimų saugumo (Goldhill et al., 2009), Didžiosios Britanijos kritinès būklès suaugusių pacientų transportavimo (3-iasis leidimas) (Whiteley et al., 2011) gairès, protokolai, patvirtinti Airijoje siekiant užtikrinti saugų tarphospitalinių pacientų pervežimą (Hennessy, Dempsey, 2009; Fitzgerald et al., 2011; O'Donnell, 2011; Cowan et al., 2010; Burton, 2011; McNamara, McCormack, 2010), JAV pacientu pervežimo tarp ịstaigų vadovas, sudarytas tarphospitalinių pervežimų organizavimo darbo grupès (Robinson et al., 2006). Nors gairèse nurodoma, kaip pervežti traumini pacientą, vis dèlto labai trūksta informacijos apie sprendimų prièmimą transportuojant chirurginius ligonius, kuriems būtina skubi pagalba (Wong, Levy, 2005, p. 290). Lietuvoje rekomenduojama vadovautis trauminių pacientų pervežimo gairèmis (LR SAM ESSC, 2015).

Transportavime dalyvaujantis personalas, transportavimo komanda, kvalifikacijos atitikimas. Mažose rajoninèse ligoninėse nepakanka gydytojų anesteziologų kritiškai sunkiems pacientams pervežti. Pvz., Dublino ligoninèse intensyvios pagalbos paslaugas teikia mobilios reanimacinès pagalbos tarnybos, tačiau tik nuo 9 iki 17 val., tuo tarpu daugiausiai iškvietimų būna kitu laiku (Faheem, 2003, p. 7-8). Mokslininkų nuomone, specialios ligonių pervežimo specialistų komandos turètų pagerinti kritiškai sunkių pacientų būklę ir sumažinti ankstyvą mirtingumą (Ligtenberg et al., 2005, p. 449; Wong, Levy, 2005, p. 293; Kue et al., 2011, p. 159). Nurodoma, kad specializuotos pervežimų komandos ir tinkama ịranga sumažina padidejjusią riziką transportuojant (Oakley, 1999, p. 61; Lieshout et al., 2008, p. 1269; Kue et al., 2011, p. 159). Ten, kur dirba patyrę darbuotojai, prieš transportavimą atliekamų intervencijų kokybė dažnai geresnè už mažiau ịūdžių turinčiujų teikiamą pagalbą. Taip yra todèl, kad labiau patyrę darbuotojai geba ịvertinti būklès sunkumą ir iš anksto numatyti problemas, kuriu gali kilti pacientą pervežant. Todèl nuo $2004 \mathrm{~m}$. nemažai ne tretinio lygio paslaugas teikiančių gydymo ịstaigų sukūre skubios medicinos pagalbos personalo grandị prièmimo skyriuose, tai galejjo lemti mirties rizikos sumažèjimą tarphospitalinių pervežimų metu (Gillman et al., 2013, p. 149). Mokslinèje literatūroje minima, kad tik kai kuriuose Nyderlandų regionuose naudojamasi visiškai ịrengtais intensyvios medicinos pagalbos automobiliais, kuriuose lydinčią komandą sudaro intensyvios medicinos pagalbos gydytojas ir slaugytoja, tuo tarpu daugelyje ịprastu greitosios 
medicinos pagalbos automobilių lydintysis yra tik gyvybę palaikyti gebantis paramedikas (Ligtenberg et al., 2005; Lieshout et al., 2008, p. 1270). Maždaug 90 \% pervežimų organizuojami siunčiančios įstaigos personalo, naudojant tos įstaigos irangą ir transportą. Tačiau mažų ligoninių medicininis ir slaugos personalas dažnai netinkamai apmokytas ir neturi reikiamos patirties. Surengus saugaus pacientų pervežimo ir gaivinimo kursus patikimai ịrodyta, kad vaikų pervežimai, atliekami pediatrų, yra saugesni ir daug efektyvesni nei suaugusių pacientų (Gray et al., 2004, p. 282; Kue et al., 2011, p. 159).

Kad pervežimo komandos efektyviai naudotų išteklius, iggautų reikiamos patirties ir nepamirštu ịūdžių, būtina rengti personalo mokymus. Pvz., kritinès būklès vaikams pervežti reikia specialiu ịgūdžių, lydintieji asmenys turi būti gydytojas ir slaugytoja, turintys pediatrinių intensyvios priežiūros ịgūdžių ir nuolat besipraktikuojantys. Vis dèlto nemažai kritiškai sunkių pacientų tarp ligoninių transportuojami lydint nepatyrusiems praktikantams, retai prižiūrint didesnę patirtị turinčių medikų, tai gali lemti rimtas komplikacijas. Specializuota pervežimo komanda tai gerai parengta komanda, kuri atvyksta iš tretinio lygio paslaugas teikiančios gydymo ịstaigos tam, kad pervežtų kritinès būklès pacientus iš siunčiančios ligoninès. Tokia komanda gali suteikti aukščiausio lygio sveikatos priežiūros paslaugas pacientą transportuojant. Šią pervežimo formą rekomenduoja Airijos intensyvios priežiūros draugija (Faheem, 2003, p. 13-25).

Amerikos intensyvios medicinos tarybos pateiktose gairèse nurodoma, kad kritiškai sunkų pacientą turètų lydèti bent du žmonès, kartu su reanimobilio vairuotoju, tarp jų būtinai gydytojas, slaugytoja ar paramedikas, turintis aukštesnio lygio gyvybės palaikymo ịgūdžių (Faheem, 2003, p. 26; Wong, Levy, 2005, p. 293; Chatwin, 2011, p. 13).

Mokslininkų atlikti tyrimai atskleidè, kad personalas jau po 15 min. trunkančių pratybų geba priimti teisingus sprendimus, susijusius su paciento pervežimu, remdamasis gairèmis, kuriose pagrindinis dèmesys skirtas diagnozei ir paciento būklei (Lieshout et al., 2008, p. 1272).

Transportavimo būdai ir paciento stebėsena ji transportuojant. Dažniausi tarphospitaliniai pacientų transportavimo būdai: greitosios pagalbos automobiliu (56,6\%), privačiu automobiliu (42,3\%), sraigtasparniu (0,6\%), lèktuvu $(0,1 \%)$ (Rourke, Kennard, 2001, p. 297). Medicininè evakuacija orlaiviais - tai nukentejusiuju gabenimas oro transportu i gydymo ịstaigą arba iš vienos gydymo ịstaigos ị kitą (BATLS, 2008, p. 15-22). Oro transportas, kaip galimybè, turi būti svarstoma, kai atstumas didesnis nei $80 \mathrm{~km}$ ar pervežimo trukmè ilgesnè nei 90 min. (Gray et al., 2004, p. 282). Nors oro transportas, toks kaip sraigtasparnis, tampa vis labiau prieinamas, tačiau nebūtinai jis yra idealus, jei nèra nusileidimo aikštelès greta prièmimo skyriaus, specialiai oro transporto saugumo, bendravimo, 
evakuacijos ir kitų procedūrų apmokyto medicininio personalo. Vis dèlto kariniai sraigtasparniai nėra skraidantys greitosios pagalbos automobiliai, pagalbos teikimo galimybės skrydžio metu ribotos, todèl esant kritiškai paciento būklei ribotos ir sužeistujų evakavimo sraigtasparniais galimybès (Goldhill et al., 2009, p. 12; BATLS, 2008, p. 15-24). Be to, oro transporto paslauga yra brangi ir turima mažai duomenų apie sraigtasparnių saugumą, nepageidaujamus įvykius taip transportuojant. Aukštas triukšmo lygis trikdo stebèseną, pacientams kyla hipotermijos ir kitų grèsmių. Atsižvelgiant ị šiuos aspektus, vertesnis ir priimtinesnis pacientams transportuoti yra antžeminis būdas, t. y. greitosios medicinos pagalbos automobiliais (Faheem, 2003, p. 28-29).

Lietuvoje medicininis sraigtasparnių naudojimas yra gana ribotas. Šiuo metu galimas transportavimas sraigtasparniais: Mi-8T, Eurocopter 120B Colibri, Eurocopter AS365N3+ „Dauphin“, Eurocopter 135 ir Eurocopter 145. Pastarasis tinkamiausias, nes yra didesnis, juo gali skristi daugiau personalo, yra vietos sudètingai medicininei ịrangai.

Kai kurių autorių (Bartolomeo et al., 2001) nuomone, ikihospitalinès pagalbos teikimo modelis, kai pagalbą teikia gydytojas, taikantis pažangią gyvybès palaikymo traumų atvejais metodiką, be to, transportavimui naudojamas sraigtasparnis, yra pranašesnis už modelị, kai transportavimui naudojamas antžeminis transportas ir pagalbą teikia paramedikas. Idealiu atveju transportuojant stebėsenos galimybės ir parametrų matavimo lygis turètų būti tokie pat, kaip ir operacinejje ar intensyvios terapijos palatoje. Visi svarbūs dokumentai turi būti perduodami kartu su pacientu. Tačiau paciento stebėsena ir lydinčio personalo igūdžių dažnai nepakanka. Dẻl to transportuojant vyksta nemažai nepageidaujamų îvykių tiek su vaikais, tiek suaugusiaisiais. Nepageidaujami ịvykiai turi būti registruojami ir nedelsiant imamasi priemonių šalinti neigiamas pasekmes (Gray et al., 2004, p. 283).

Lietuvoje transportavimo mokymai vyksta tik pagal tam tikras programas (traumų, naujagimių). Specialių tobulinimosi kursų gydytojams pacientų transportavimo tema iki šiol neorganizuojama, akivaizdu, kad jų trūksta. Aukštus personalo, transporto, stebėsenos įrangos reikalavimus šiuo metu Lietuvoje geriausiai atitinka skubios konsultacinès pagalbos brigados: suaugusiujų anesteziologo reanimatologo su slaugytoja, kardiologo ar anesteziologo reanimatologo, vaikų intensyvios terapijos ir neonatologo su slaugytoja.

Transportavimo rezultatai, išeitys. Transportavimas turètų vykti esant stabiliai paciento būklei, siekiant užtikrinti optimalią paciento sveikatos būklę. Nediagnozuoti sužalojimai, nepakankamas gydymas, neịvertintas kvẻpavimo ar kraujotakos nepakankamumas ir nenumatyti nepageidaujami ịvykiai, galimi transportuojant, gali neigiamai paveikti ligos išeitis (Gray et al., 2004, p. 283; Ligtenberg et al., 2005, p. 448; Kue et al., 2011, p. 154). 
$32 \%$ transportuojamų pacientų būna kritinès būklès, 2,1 \% jų miršta (Gillman et al., 2013, p. 149). Šis skaičius nèra didelis, kiti autoriai nurodo mirtingumą nuo 3 iki $27 \%$ netgi ten, kur pervežant pacientą dalyvauja specialiai apmokytos komandos (Ligtenberg et al., 2005, p. 449).

Uždelsus patekimą į ligoninę, taip pat pacientus vežant ne GMP brigadai, įskaitant ir paramedikus, tokių pacientų mirštamumo rizika ligoninèse didejja (Leet et al., 2012, p. 767-775).

Nepageidautiną rezultatą lemia ir lydinčio personalo kvalifikacija. Nemažai kritiškai sunkių pacientų tarp ligoninių pervežami lydint nepatyrusiems praktikantams, retai - prižiūrint didesnę patirtị turinčiam medikui, tai gali lemti rimtas komplikacijas. Pervežamų pacientų mirtingumas yra $20 \%$ didesnis, lydint gydytojams, kurie neturi pediatrinės ar intensyvios medicinos pagalbos teikimo ar pratybų patirties. Sunkių trauminių pacientų mirtingumas ir gulejjimo ligoninėje laikas reikšmingai sutrumpèdavo, kai jie iškart po pradinio būklès stabilizavimo įvykio vietoje patekdavo ị specializuotus traumų centrus (Faheem, 2003, p. 13-26). Lyginant tiesiogiai pervežamų pacientų grupę su tais, kurie pervežami tarp ligoninių, pastarujų mirtingumo rizika transportuojant, mirtingumas prièmimo skyriuje ir mirtingumas stacionarizavus buvo didesni. Pervežti pacientai pastebimai ilgiau gulèjo ligoninèje ir intensyvios terapijos skyriuje (Sampalis et al., 1999, p. 295). Tačiau esant situacijai, kai pacientas pateko ị rajoninę ligoninę, nepaisant didesnès rizikos, pritariama ir antriniam transportavimui, nurodant, kad trauminiu pacientų mirtingumas rajoninėse ligoninėse gerokai didesnis negu tų pacientų, kurie buvo pervežti ị specializuotus traumos centrus (Schoettker, 2003, p. 187; Meisler, 2009, p. 218-223). Yra patvirtintų ịrodymų, kad sveikatos priežiūros kokybė pagerėja, jeigu naudojamasi specialistų komandomis iš priimančios įstaigos (Gray et al., 2004, p. 282; Kue et al., 2011, p. 153). G. Bellingan ir kt. atliktame tyrime (2000, p. 740-744) nurodoma, kad transportavimas lydint specialiai apmokytai komandai, lyginant su standartiniu transportavimu greitosios pagalbos mašina, kai lydi gydytojas iš siunčiančios gydymo ịstaigos, lemia tai, jog daugiau pacientų atvežama stabilios būklès, o mirtingumas per pirmąsias 12 valandų sumažèjo nuo $7,7 \%$ iki $3 \%$.

\subsection{Teorinès dalies įžvalgos remiantis tyrimo rezultatais}

Skubios medicinos pagalbos ikihospitalinių ir tarphospitalinių pacientų srautų valdymo situacija Lietuvoje. Atliekant tyrimą respondentų teirautasi, ar GMP brigadoms tenka pervežti pacientus, kuriems būtina skubi medicinos pagalba, tarp ligoninių. Didžioji dalis apklaustujų (89,5 \%) atsakè, kad tai 
atlieka. GMP brigados plačiai naudojamos pacientų transportavimui tarp ligoninių. Kokio tipo GMP brigados ir kokie transportavimo atvejai, dažniausiai netirta.

GPM vadovų klausta, ar yra nustatyti ir patvirtinti kriterijai, ị kurią gydymo ịstaigą reikia vežti pacientus, kuriems būtina skubi medicinos pagalba. Tarp atsakymų dominuoja nuomone (78,9\%), kad GPM tokius patvirtintus kriterijus turi. Igyvendinant trečiają sveikatos priežiūros ịstaigų ir paslaugų restruktūrizavimo programą (Žin., 2009, Nr. 150-6713), iš dalies šie kriterijai nustatyti SAM ịsakymu (Žin., 2010, 21-1010), reglamentuojančiu pacientų siuntimą ị atitinkamo lygmens sveikatos priežiūros įstaigas, kur jiems bus suteiktos stacionarinės skubios ir planinès paslaugos. SAM ịsakymais (TAR, 2014-00358, 2014-01758) numatyta ir pacientų transportavimo GMP insulto ir miokardo infarkto atvejais tvarka. Tačiau iš pateiktų atsakymų galima daryti prielaidą, kad teisiniai dokumentai nepakankamai aiškiai reglamentuoja, kur pacientas turi būti transportuojamas, nepakankamai veikia tarphospitalinių pervežimų sistema. Esamas teisinis reglamentavimas nevisiškai atitinka GMP ir stacionarinių ASPI paslaugų teikimo galimybes. Be to, nereglamentuoti pacientų pervežimai tyrimų atlikimo ar skubios medicinos pagalbos (tai dalis skubios ambulatorinès paslaugos), paslaugų teikimo kitose ligoninėse arčiausiai paciento esančių ligoninių nedarbo metu (kai neteikiamos atitinkamo specializuoto profilio paslaugos), paciento atgalinio transportavimo atvejais.

Pacientų srautų valdymo optimizavimo būdai ir priemonès. Sveikatos priežiūros ịstaigu poreikị pacientus pervežti ị kitas ligonines konstatavo didžioji dalis respondentu ( 86,9 \%). Nors rezultatai statistiškai reikšmingai nesiskiria atsižvelgiant ị visas respondentų sociodemografines charakteristikas - amžių, lytị, darbo stažą, SPI steigèją, PSP specialistų tipą ir SPI lygmenị ( $\chi^{2}$ kriterijus, $p>0,05)$, jie panašūs ị GMP vadovų atsakymų rezultatą. Rezultatai dẻl tarphospitalinių pervežimų poreikio pagal ịstaigų lygmenị (rajono, regiono, Respublikos) atrodo labai panašiai. Didžiausias pacientų transportavimo poreikis yra rajono lygmens ligoninėse - 89,7 \%, šiek tiek mažesnis - regiono ligoninėse $(86,4 \%$ ), mažiausias - Respublikos lygmens ligoninèse (78,6 \%). Tikètina, kad iš pastaruju ligoninių labiausiai vykdomas tretinis pacientų transportavimas.

Dauguma respondentų kaip pagrindinę tarphospitalinio transportavimo priežastị ịvardijo ịstatymiškai apribotą ịstaigos veiklą (atsakymas atitinka didžiausią vertinimų vidurkị: $3,-+1,94$ SD). Šio atsakymo vidurkis statistiškai reikšmingai didesnis, lyginant su likusių atsakymų vidurkiais (t-testas priklausomoms imtims, $p<0,01)$. Vertinant transportavimo tarp ligoninių priežastis, antroje vietoje yra specialistų trūkumas (1 pav.). Atsakymo rezultatai atskleidžia, kad didžiausią pacientų transportavimo paslaugų poreikị lėmé ne staigus kritinių pacientų padaugèjimas ar įrangos trūkumas, bet su vykdoma regionalizacija ir paslaugų centralizavimu susiję procesai. Tyrimo rezultatų duomenys atitinka užsienio autorių pateikiamus 
duomenis (Lieshout et al., 2008, p. 269; Gray et al., 2004, p. 281), kiti autoriai labiau akcentuoja technines, procedūrines, ištyrimo bei ne klinikines priežastis: lovų trūkumą, nepakankamą darbuotojų skaičiu, kitą paciento gyvenamosios vietos geografinę vietovę, nei yra gydymo ịstaiga (Warren, 2004, p. 256).

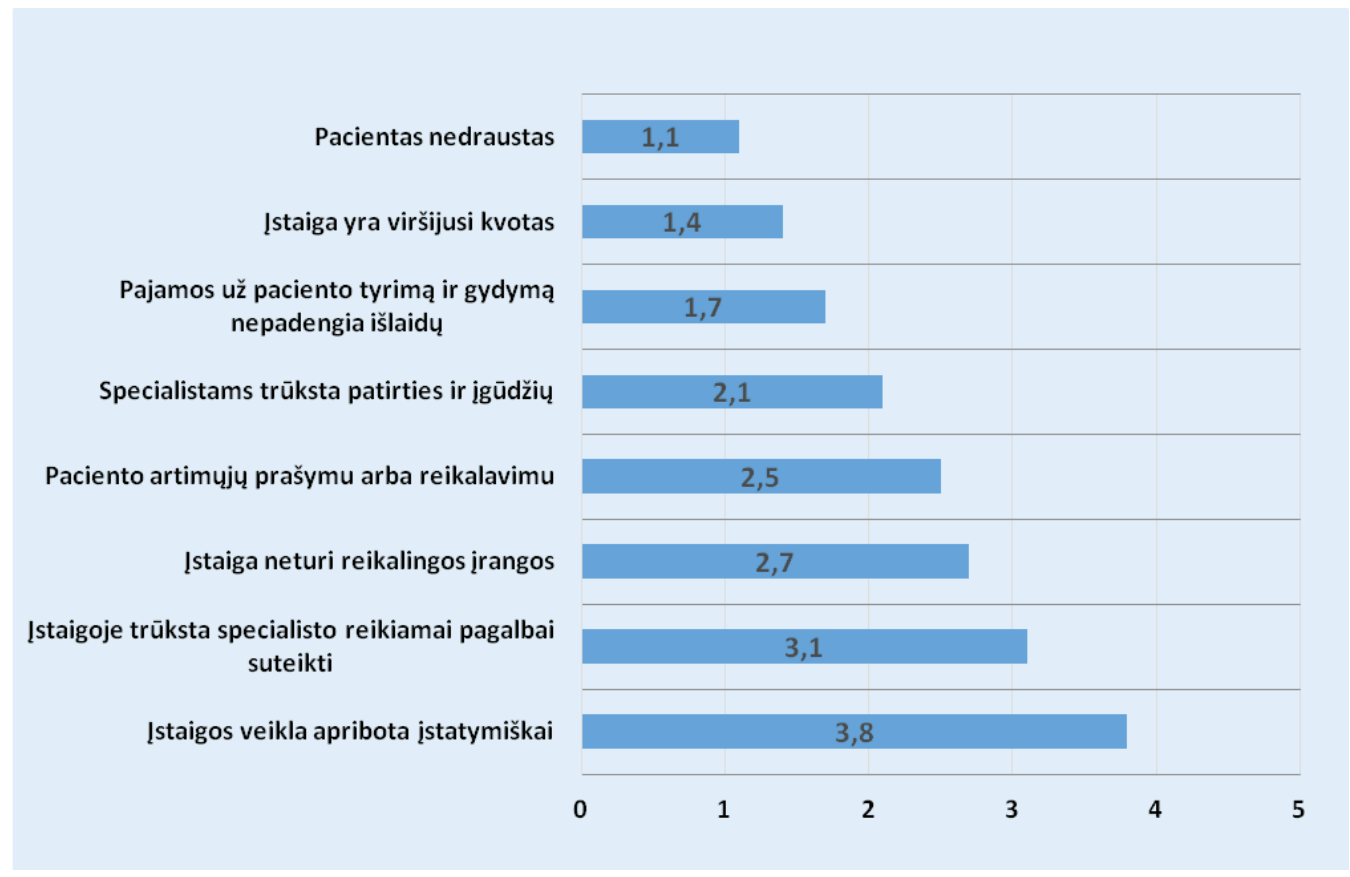

1 pav. Transportavimo priežastys pagal dažnumą (vidurkiai, balais)

Didžioji dalis gydymo įstaigų pacientų pervežimui renkasi skubios konsultacinės pagalbos reanimobilị (vertinimų vidurkis balais $-4,1-+1,25 \mathrm{SD}$ ). Šio atsakymo vidurkis (išreikštas balais) statistiškai reikšmingai didesnis, lyginant su likusių atsakymų vidurkiais (t-testas priklausomoms imtims, $p<0,01$ ) (2 pav.). Šie duomenys atitinka ir užsienio autorių duomenis, pastarieji teigia, kad pervežimams tikslingiausia rinktis specializuotas pervežimų komandas ir tinkama ịranga aprūpintus reanimobilius. Airijos intensyvios priežiūros draugija, Amerikos intensyviosios medicinos tarybos gairès nurodo, kad specializuotos pervežimų komandos labiausiai tinka pervežti kritinès būklès pacientus, nes gali suteikti aukščiausio lygio priežiūros paslaugas transportuojant ir taip sumažina riziką (Wong, Levy, 2005, p. 293; Faheem, 2003, p. 25-26). Remiantis apklausos duomenimis, nemažai pervežimų atlieka GMP pradinio gyvybès palaikymo brigados, vežama ir ligoninès sanitariniu transportu su slaugytoja. Artimujų transportu ir ligoninès sanitariniu transportu tik su vairuotoju pervežama mažiausiai pacientų. Paskirais atvejais pa- 
cientų artimieji patys imasi iniciatyvos transportuoti: jei nesunki paciento būklè, tuo metu nèra galimybès greitai gauti pervežimui būtino transporto, dèl ịvairių socialinių ir asmeninių aplinkybių.

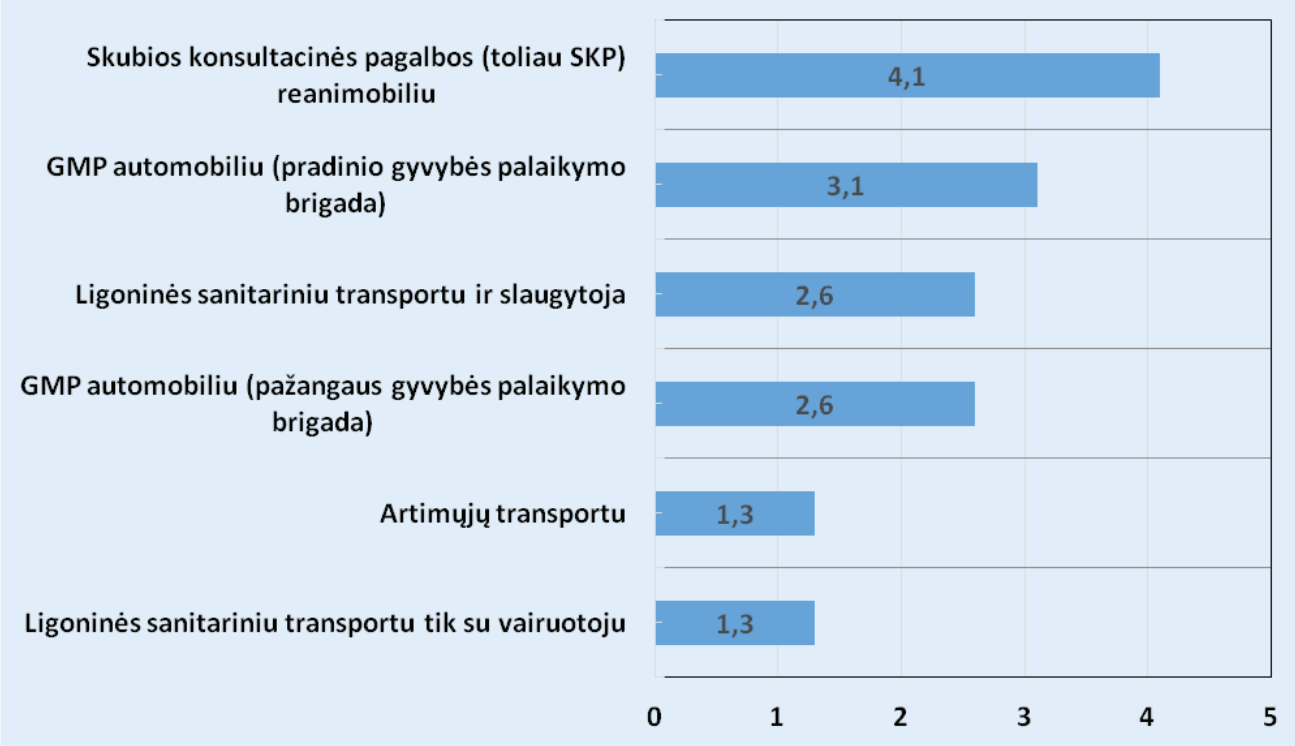

2 pav. Pacientų pervežimo tarp gydymo įstaigų būdai (vidurkiai, balais)

Skubios medicinos pagalbos srautų valdymo tobulinimo priežastys ir priemonès. Antrini pervežimą galima taikyti tik numačius, kad tai pagerins paciento klinikinę išeitị. Tai būtina atlikti būdu, kuris nemažintų pagalbos teikimo kokybès (Gray et al., 2004, p. 281; Iwashyna, 2012, p. 2471). Sprendimas dèl perkèlimo turi būti priimamas tik ịvertinus tikètiną naudą, atsižvelgiant ị potencialią riziką transportuojant (Warren, 2004, p. 256). Prieš pervežant būtina tiksliai nustatyti paciento diagnozę, jị tinkamai gydyti, stabilizuoti, mediciniškai ịvertinti transportavimo riziką ir naudą, koordinuoti saugų pervežimą (Rourke, Kennard, 2001, p. 297; Goldhill, 2009, p. 2). Kritinès būklès paciento pervežimo paslaugos regionalizavimas yra naudingas pacientui, nes taip i specializuotos pagalbos centrus atvyksta greičiau (Faheem, 2003, p. 27). Todẻl tyrimu siekta nustatyti, kokius veiksmus siūlo atlikti respondentai, jei dẻl paciento būklès ir pervežimo konsultuojamasi su SKP gydytojais konsultantais. Didžiausias vertinimų vidurkis (4,4-+1,31SD) teko atsakymui: „Pacientai turi būti transportuojami tik ị tą ligoninę, kurios konsultantai paskirti konsultuoti, kad būtu pacientu perimamumas, būklès stebèjimo bei gydymo tęstinumas" (3 pav.). Tačiau vidurkių skirtumai lyginant tarpusavyje visas atsakymų kategorijas statistiškai nereikšmingi (t-testas 
priklausomoms imtims, $p>0,05)$. Šis rezultatas atitinka užsienio mokslininkų tyrimų duomenis, pastarieji teigia, kad sveikatos priežiūros kokybẻ būna geresnè, jeigu naudojamasi specialistų komandomis iš priimančios įstaigos. Tikètina, kad transportavimas tokiu atveju trunka trumpiau. Vis dèlto atlikto tyrimo duomenys rodo, kad ir kiti veiksmai yra panašiai vertinami, kai kolegiškai bendradarbiauja ir komunikuoja skirtingu įstaigų specialistai. Kitų autorių (Gray, Bush, Whiteley, 2004, p. 282) duomenimis, maždaug 90 \% pervežimų organizuojami naudojant siunčiančios įstaigos darbuotojus, tos įstaigos įrangą ir transportą, net jei medicininis ir slaugos personalas dažnai netinkamai apmokytas ir neturi reikiamos patirties, nes galima manyti, atsižvelgiama ne tik ị priežiūros kokybę, bet ir ị išlaidas.

Kviesti konsultacijai gydytoją anesteziologąreanimatologą, kadangi esant poreikiui, jie gali transportuoti pacientą dèl bet kokios patologijos

Su reikiamais specialistais pasikonsultuoti telefonu, jei jų atvykimas i ligoninę nèra būtinas

Pacientai turi būti transportuojami tik j̇ tą ligoninę, kurios konsultantai konsultuoja, kad būtų pacientų perimamumas, būklès stebejjimo bei gydymo tęstinumas

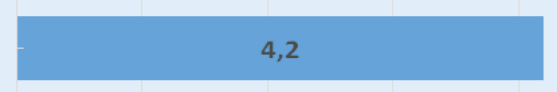

4,3

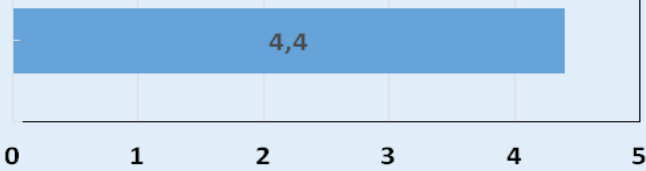

3 pav. Siūlomi atlikti veiksmai, kai dèl paciento būklès ir pervežimo konsultuojamasi su SKP gydytojais konsultantais (vidurkiai, balais)

Nors sunkios būklės trauminių ar klasterinių (sergančių insultu ar infarktu) pacientų transportavimas iš dalies reglamentuotas, kyla teisinių ginčų, girdisi nuomonių ar diskusijų, kad pacientas buvo nuvežtas ne ị tą gydymo ịstaigą. Tyrimu siekta išsiaiškinti, ar skiriasi respondentų nuomonès, kur turi būti transportuojamas pacientas, kai yra aiškus ir kai neaiškus susirgimo / traumos pobūdis / diagnozè. Abiem atvejais daugiausia respondentų pritarè, kad pacientą reikètų transportuoti ị artimiausią atitinkamo lygmens ASPI ar funkcinio klasterio centrą, jei transportuojant yra galimybe suteikti pagalbą ir užtikrinti paciento saugumą. Šių atsakymų vidurkis statistiškai labai reikšmingai didesnis už visus likusius atsakymų variantų vidurkius (t-testas priklausomoms imtims, $p<0,01$ ) (4 ir 5 pav.). 
Transportuoti i gydymo jstaigą, kurią pasirinko pacientas ar jo atstovas

[ artimiausią atitinkamo lygmens ASP ar ar funkcinio klasterio centrą, nepriklausomai nuo paciento būklès ir galimybių transportavimo...

Teikti pagalbą vietoje iki būklès stabilizavimo ir tada transportuoti $j$ artimiausią atitinkamo lygmens ASPI ar funkcinio klasterio centrą

Transportuoti i artimiausios gydymo jistaigos PSPS, kur paciento būklè gali būti stabilizuota

[ artimiausią atitinkamo lygmens ASP | ar funkcinio klasterio centrą, jei transportavimo metu yra galimybè teikti pagalbą ir užtikrinti...

\section{1,5}

0 1

\section{3,7}

3,7

4,7

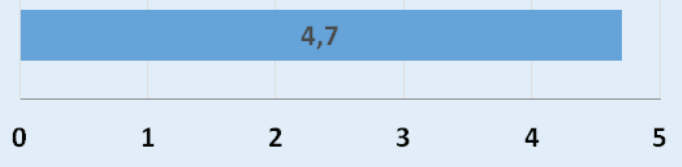

4 pav. Transportavimo vietos pasirinkimas esant sunkiai paciento būklei, bet neaiškiam susirgimo / traumos pobūdžiui / diagnozei (vidurkiai, balais)

Transportuoti i gydymo jistaigą, kurią pasirinko pacientas ar jo atstovas

[ artimiausią atitinkamo lygmens ASP| ar funkcinio klasterio centrą, nepriklausomai nuo...

Transportuoti $\mathbf{i}$ artimiausios gydymo jstaigos PSPS, kur paciento būklè gali būti stabilizuota

Teikti pagalbą vietoje iki būklès stabilizavimo ir tada transportuoti j artimiausią atitinkamo...

[ artimiausią atitinkamo lygmens ASP I ar funkcinio klasterio centrą, jei transportavimo..

0

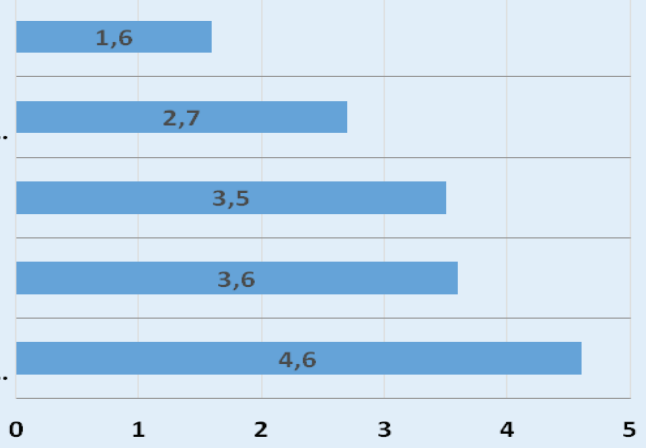

1

5 pav. Transportavimo vietos pasirinkimas esant sunkiai paciento būklei, bet aiškiam susirgimo / traumos pobūdžiui / diagnozei (vidurkiai, balais)

Esant sunkiai paciento būklei, bet aiškiam susirgimo / traumos pobūdžiui / diagnozei, paciento pervežimas tarp ligoninių paprastai aptariamas. Vis dèlto, esant tokioms būklèms, dažniausi yra pirminiai transportavimai, kai su gydymo ịstaigomis nesiderinama. 
Atsakymuose pateiktos nuomonès atitinka užsienio autorių duomenis, kad pacientus tikslingiausia vežti ne ị arčiausiai esančią, kaip gali pasirodyti vertinant atsakymus, bet ị artimiausią atitinkamo lygio gydymo ịstaigą, atsižvelgiant ị sužalojimo pobūdị ar ligą. Artimiausia atitinkamo lygio ASPĮ nebūtinai bus arčiausiai esanti ligoninè. Kita vertus, yra papildoma sąlyga, kad transportuojant turi būti galimybè užtikrinti paciento saugumą. Turbūt tyrimo rezultatus nulėmè tai, kad tiek GMP, tiek ir stacionarinių ịstaigų specialistai realiai vertina esamą situaciją, nes transportavimas užtrunka ilgai ir tuo metu būtina užtikrinti pagalbą bei stebèseną. Tokias galimybes šiuo metu Lietuvoje turi tik SKP tarnybos reanimobiliai, iš dalies ir pažangaus gyvybès palaikymo GMP brigados.

Ivvertinus atlikto tyrimo rezultatus pateikiama „Pacientų, kuriems būtina skubi medicinos pagalba, tarphospitalinių pervežimų srautų schema“" (6 pav.).

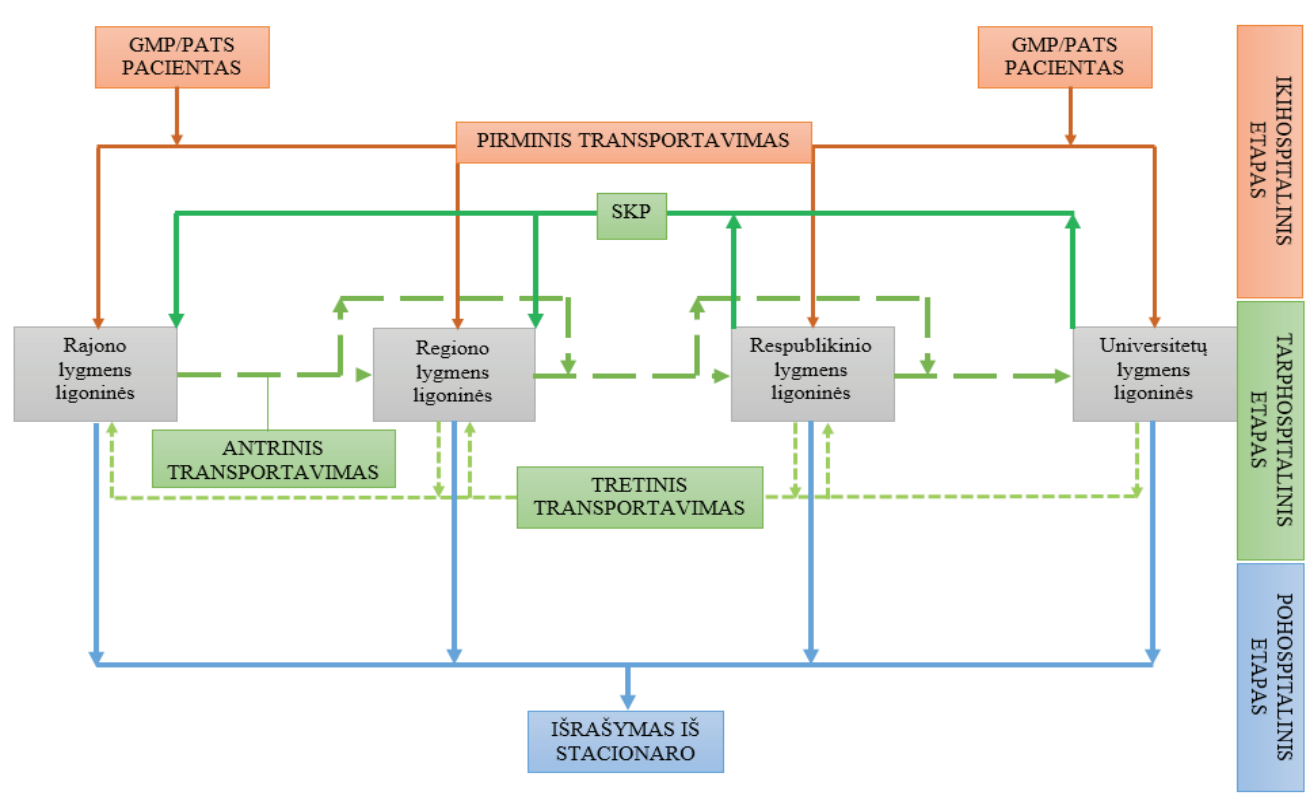

6 pav. Pacientų, kuriems būtina skubi medicinos pagalba, tarphospitalinių pervežimų srautų schema (sudaryta autorių)

\section{Diskusija}

J. Verikienės, D. Jankauskienės (2012) teigimu, vykdant sveikatos priežiūros reformą pablogėjo paslaugu prieinamumas pacientams pas šeimos gydytojus ir ambulatorinio antrinio lygio specialistus, tai savo ruožtu lėmè, kad restruktūri- 
zuotuose rajonuose GMP paslaugomis besinaudojančių pacientų dalis didesnè nei kituose rajonuose. Net 2/3 visų pacientų Lietuvoje (restruktūrizacijos paveiktuose rajonuose šis rodiklis dar didesnis) kreipiasi ị stacionarą dẻl ūmių susirgimų ir traumų. Pacientai iš anksto pas šeimos gydytoją nesiregistruoja, bet vyksta tiesiai ị gydymo ịstaigą. Tokiu atveju ịstaigoms, kurios teikia daugiaprofilines paslaugas, kyla problemų planuojant ịstaigos išteklius, sąnaudas ir veiklos valdymą, nes galima numatyti tik apie trečdali pacientų srauto.

Šiuo metu vykdoma sveikatos priežiūros reforma (eilinis restruktūrizacijos etapas) apima paskiras sveikatos priežiūros paslaugas ir orientuojasi ị tai, kaip sumažinti lovų skaičių stacionaruose dèl neveiksmingo jų panaudojimo, taip siekiama perskirstyti (bet ne sutaupyti) finansavimą. Gali būti, kad dèl SAM nustatytų kriterijų neatitikimo eilinị kartą bus tam tikrų ligoninių skubios medicinos pagalbos paslaugas teikiantys skyriai. Kokią skubią medicinos pagalbą ir kokio lygio pacientams bus galima suteikti vietoje, kaip ir kuo prireikus transportuoti pacientus ị kitas ligonines ir kaip užtikrinti pagalbos teikimą transportuojant, nelabai aišku. Dalis pacientų tarp ligoninių šiuo metu transportuojama pagal skubios konsultacinès pagalbos (SKP), skubios specializuotos konsultacinès pagalbos ir klasteriu programas. Kadangi administravimo ir struktūrizuotos apskaitos nėra, duomenys neapskaitomi ir viešai nepateikiami, todèl išsamiau neanalizuojami. Dèl informacijos trūkumo ị kai kuriuos klausimus sudètinga atsakyti, o tai svarbu siekiant valdyti tarphospitalinius pacientų srautus: kokio amžiaus pacientai ir dèl kokių patologijų pervežami tarp ligoninių (a), kaip šie pacientų srautai paskirstyti (b), kokio pavaldumo brigados (GMP ar stacionarinių ASPI) atlieka transportavimą ir kokią pagalbą teikia transportuojant (c), kokiu laiku vyksta ir kiek trunka transportavimas (d), kiek nuo patekimo ị pirmą ligoninę praejję laiko iki antrinio transportavimo ir kokia pagalba buvo suteikta (e), kokiai daliai pacientų ir kokios apimties operacijos (procedūros, manipuliacijos ir pan.) atliktos per 24 val. po pervežimo (f), dẻl kokių priežasčių mirè per pirmas 24 val. atvežti pacientai (g), kodèl pacientams, kurie buvo kritinès būklès, taikytas antrinis transportavimas SKP reanimobiliais $(\mathrm{h})$ ?

Nepaisant kylančių klausimų, dalis skubios medicinos pagalbos teikimo ir pacientų transportavimo problemų (taip pat ir finansinių) sprendžiama pagal SKP programą. SKP reglamentavimas dažnai keistas didinant arba mažinant teikiamos pagalbos apimtis pagal profilius, taip pat keičiant paslaugas teikiančias ịstaigas ir apimamus regionus. Šiuo metu SKP paslaugų teikimo apimtys keičiasi dèl vykstančios regionalizacijos - klasterizacijos proceso. Šiame procese dalis pacientu gabenama tiesiai ị ligonines apskričių GMP pajëgomis. SKP tarnyba neskirta teikti pagalbą ịvykio vietoje, tačiau turi transportuoti pacientus ne tik ị ligoninę, kurios bazei priklauso, bet ir ị kitas ligonines. Dažniausiai pacientas transportuojamas i 
Vilniaus universiteto Santariškių klinikas ar LSMU Kauno klinikas. Taip yra todèl, kad paskirais atvejais pagalba centralizuota šiose klinikose, pavyzdžiui: nudegimai, vaikų ar suaugusių kardiochirurgija, perinatologijos programoje nurodyti atvejai, kiti retesni atvejai.

Lietuvoje šiuo metu skubi medicinos pagalba ne visose ligoninèse teikiama ištisą parą arba teikiama nepakankamo lygio pagalba. Medicinos personalo sudètis ir pasirengimo lygis ligoninèse pacientams neužtikrina reikiamos skubios medicinos pagalbos. Dažnas pacientų, kuriems būtina skubi medicinos pagalba, transportavimas ị visų profilių ir atitinkamo lygio skubios medicinos pagalbos teikimą užtikrinančias ligonines. Vienas esminių pacientų transportavimo reikalavimų nenutrūkstamas skubios medicinos pagalbos paslaugų teikimas pacientą transporuojant: paciento būklè turi būti nuolat stebima, prireikus skiriami vaistai ar net atliekamos medicininès intervencijos. Suteikti tokią medicininę pagalbą transportuojant gali tik parengta komanda, dažniausiai tai anesteziologas reanimatologas, neonatologas ar vaikų intensyvios terapijos gydytojas su slaugytoja. Tam būtinas ir atitinkamai sukomplektuotas greitosios medicinos pagalbos automobilis - reanimobilis. Deja, mažos rajoninės ar net regioninès ligoninès neturi galimybių siųsti anesteziologo reanimatologo su slaugytoja. Be to, rajono ligoninèse anesteziologas reanimatologas budi ne visą parą, jis gali budèti namuose. Abiem atvejais, prireikus pacientą transportuoti, ligoninè lieka be gydytojo anesteziologo reanimatologo ir be slaugytojos, kuri darbo metu turi prižiūrèti pacientus skyriuje. Dažniausiai išvykimo trukmè siekia 2-6 valandas. Tai priklauso nuo atstumo tarp ligoninių ir pervežimo metu teikiamos pagalbos. Pasitaiko atvejų, kai rajono ar regiono ligoninès tokius pacientus išveža be gydytojo anesteziologo reanimatologo ir slaugytojo, su nepasirengusio slaugytojo ar kito nepakankamai kvalifikuoto personalo palyda. Tokių pacientų sveikatos išeitys dažnai būna blogos.

Specializuotos reanimacinès pagalbos teikimas pacientus transportuojant gali būti užtikrinamas ir GMP pažangaus gyvybès palaikymo brigados. Galima daryti prielaidą, kad antrini transportavimą gali atlikti bet kuri GMP - tiek bet kurios ligoninės, tiek GMP tarnybos. Tačiau ne visos jos yra paruoštos ir pritaikytos sunkių pacientų ilgalaikiam transportavimui. GMP pažangaus gyvybės palaikymo brigadų, esančių didžiuosiuose miestuose, pagrindinis uždavinys - transportuoti pacientus iš ịvykio vietos, esant sunkiems sužalojimams, arba transportuoti pacientus, esant ūmiai sunkiai sveikatos būklei, t. y. atlikti pirminị transportavimą. Tokie pacientai turi būti transportuojami ị arčiausiai esančias specializuotą pagalbą galinčias suteikti ligonines. Jei paciento būklè labai sunki, jị galima vežti ị arčiausiai esančią ligoninę ir perduoti personalui, kad stabilizuotų būklę ir paruoštų toliau transportuoti. Paruošus pacientą transportuoti, ligoninei kyla ta pati pervežimo problema, aprašyta anksčiau. GMP pažangaus gyvybės palaikymo briga- 
dos iškvietimas įmanomas, tačiau ligoninių mažai taikomas, nes už tokị paciento pervežimą ligoninè turi apmokèti GMP tarnybai. Kad pacientas būtų pervežtas iš vienos ligoninès ị kitą (aukštesnio ar to paties lygio, bet teikiančią specializuotas paslaugas), procesą būtina suderinti su siunčiančia ir priimančia ligonine. Dažna problema, kai siunčianti ligoninė neinformuoja apie pervežamą pacientą, arba neatlieka kruopštaus ištyrimo, nors tai priklauso pagal ịstaigos licencijoje nurodytas paslaugų teikimo apimtis ir specialiuosius paslaugų teikimo reikalavimus. Dažnai siunčiančios ligoninès gydytojai pateikia klaidingą informacija apie paciento būklę, nurodo, kad būklę ištirti sutrukdè neva sugedusi įranga ar panašiai. Ne mažiau aktuali pervežamų pacientų problema - pervežami nedrausti pacientai, nors pati ligoninè galètų reikiamą pagalbą suteikti.

Reglamentavus pacientų siuntimą ị atitinkamo lygio sveikatos priežiūros ịstaigas, kur jiems bus suteiktos stacionarinès skubios ir planinès paslaugos (Žin., 2010, 21-1010), ir nukreipus pacientų srautus teikti skubią pagalbą ,žaliaisiais koridoriais“ $\mathfrak{i}$ universitetų ligoninių prièmimo skyrius, pasirodè, kad nesuderinus, negavus leidimo transportuoti, nors paciento būklè atitinka nustatytus reikalavimus, tokių pacientų iš periferinių ligoninių niekas nelaukia. Pasitaiko atvejų, kai universitetinėse ligoninėse nėra vietų ir tenka palaukti, atvežti ligonį dažniausiai rekomenduojama po kelių dienų ar savaičiu ir tik suderinus. Net ir tais atvejais, kai pacientai atvežami iš kitų ligoninių, jie neturi pirmumo teisès ir jiems laukimo trukmė prièmimo skubios pagalbos skyriuose išauga iki keleto valandų. Tokiu atveju GMP personalas arba laukia, kol pacientą pakonsultuos, gaišta laiką ir tuo metu negali teikti kitų paslaugų, arba palieka pacientą prièmimo skubios pagalbos skyriuje. Jei pacientas po konsultacijos nestacionarizuojamas, GMP turi grịžti atgal ir pervežti pacientą i siuntusią ligoninę. Tai dvigubos laiko ir transportavimo sąnaudos. Atsižvelgiant ị atstumą tarp ligoninių, išlaidos gali būti nemažos. Dažni atvejai, kai pacientas nestacionarizuojamas, bet jo niekas - nei GMP, nei artimieji neatvyksta parsivežti. Tokie pacientai tampa ligoninių prièmimo skyrių ịkaitais ir problema. Viena vertus, tai medicininè problema, kita vertus - socialinè, trečia vertus - vadybinè.

\section{Išvados}

1. Vykdant sveikatos priežiūros paslaugų centralizavimą bei regionalizavimą, didèja tarp ligoninių transportuojamų pacientų skaičius tiek GMP, tiek ir pačių stacionarinių ASPİ transportu.

2. Dažniausiai sunkių ir kritinių pacientų antrinị transportavimą vykdo skubios konsultacinès pagalbos brigados. Jų išvykimo ị iškvietimą laiko reglamenta- 
vimas gali gerokai sumažinti transportavimo laiką ir pagreitinti kvalifikuotos medicinos pagalbos teikimą.

3. Universitetų ligoninès nepakankamai pasiruošusios SAM ịsakymais nustatyta tvarka priimti didejjanti pacientų srautą. Ne visos regiono ar rajono ligoninès turi teisę tokią pagalbą suteikti, todèl didejja transportavimui gaištamas laikas ir sąnaudos, tam reikia papildomų žmogiškujų išteklių.

4. Tinkamai organizuoti antriniai ir tretiniai tarphospitaliniai pacientų parvežimai turi ịtakos skubios medicinos pagalbos paslaugų prieinamumui ir kokybei, mažina paslaugų teikimo netolygumus ir socialinę atskirtį.

5. Dèl duomenų trūkumo apie pačių ligoninių, greitosios medicinos pagalbos, skubios konsultacinès pagalbos ir klasteriuose atliekamus pacientų pervežimus detalesnè tarphospitalinių pacientų srautų analizè negalima.

Gauta 20151202

Pasirašyta spaudai 20160307

\section{Literatūra}

ACEP Board of Directors. (2009). Appropriate Interhospital Patient Transfer. American College of Emergency Physicians. Prieiga internete: <https:/www.acep.org/Clinical---Practice-Management/Appropriate-Interhospital-Patient-Transfer/> [žiūrèta 2015-10-25].

Bartolomeo, Di. S., Sanson, G., Nardi, G., Scian, F., Michelutto, V., Lattuada, L. (2001). Effects of 2 patterns of prehospital care on the outcome of patients with severe head injury. Archives of Surgery, Vol. 136, Issue 11, p. 1293-1300.

Battlefield Advanced Taruma Life Support (BATLS). (2008). 15 skyrius, p. 1-24.

Bellingan, G. et al. (2000). Comparison of a specialist retrieval team with current United Kingdom practice for the transport of critically ill patients. Intensive Care Medicine, Vol. 26, p. 740-744.

Craig, S. S. (2005). Challenges in arranging interhospital transfers from a small regional hospital: an observational study. Emergency Medicine Australasia, Vol. 17, Issue 2, p. 124-131, Melbourne.

Faheem, M. (2003). Inter-hospital transfer of critically ill patients (how the deficiencies in the system can be overcome). Dissertation. Prieiga internete: https://www.yumpu.com/en/document/view/6686467/dissertation-inter-hospital-transfer-of-critically-ill- [žiūrèta 2015-10-25].

Fried, M. J., Bruce, J., Colquhoun, R. et al. (2010). Interhospital transfers of acutely ill adults in Scotland. Anaesthesia, Vol. 65, Issue. 2, p. 136-144.

Hennessy, J., Dempsey, A. (2009). Fitzgerald, T. et al., 2011; O’Donnell, C., 2011; Cowan, C. et al., 2010; Burton, J., 2011; McNamara, C., McCormack, H., 2010. Protocols for the Safe Inter-Hospital Transfer of Patients for the HSE Mid-West. 2009-2013. Prieiga internete: http://www.hse.ie/eng/services/list/3/hospitals/ulhospitals/ staff/resources/pppgs/IntServ/transfer.html [žiūrèta 2015-12-01].

Hoot, N. R., Aronsky, D. (2008). Systemic Review of Emergency Department Crowding: Causes, Effects, and Solutions. Health Policy and Clinical Practice / Review Article. Annals of Emergency medicine, Vol. 52, No. 2, p. 126-136.

Gillman, L., Fatovich, D., Jacobs, I. (2013). Mortality of interhospital transfers originating from an Emergency Department in Perth, Western Australia. Australasian Emergency Nursing Journal, Vol. 16, p. 144-151.

Graff, L. G. (2004). Effect of Interhospital Transfer Patterns on Hospitals' Quality Performance Measurement Results. Annals of Emergency Medicine, Vol. 44, p. 4.

Goldhill D. et al. (2009). The Association of Anaesthetists of Great Britain and Ireland. AAGBI Safety Guideline of Interhospital Transfer. Prieiga internete: https://www.aagbi.org/sites/default/files/interhospital09.pdf [žiūrèta 2015-12-01]. 
Gray, A., Bush, S., Whiteley, S. (2004). Secondary transport of the critically ill and injured adult. Emergency Medical Journal, Vol. 21, No. 3, p. 281-285.

Iwashyna, T. J. (2012). The incomplete infrastructure for interhospital patient transfer. Critical Care Medicine, Vol. 40, No. 8, p. 2470-2478.

Yorkshire Ambulance Service. (2014). Clinician Decision Algorithm for Arranging Inter Hospotal Transfers. Prieiga internete: http://www.leedsth.nhs.uk/fileadmin/services/LeedsMajorTraumaCentre/Pre-Hospital_ Care/5.pdf [žiūrèta 2015-12-01].

Klaipèdos universitetinès ligoninès Vyriausiojo gydytojo 2010-05-24 įsakymas Nr. 98 „Dẻl skubios konsultacinès pagalbos gydytojų ir specialistų konsultacijų organizavimo kitose asmens sveikatos priežiūros įstaigose, dokumentacijos pildymo ir konsultacijų apskaitos tvarkos patvirtinimo“.

Kue, R., Brown, P., Ness, C., Scheulen, J. (2011). Adverse Clinical Events During Intrahospital Transport by a Specialized Team: A Preliminary Report. American Journal of Critical care, Vol. 20, Issue 2, p. 153-162.

Lee, D. S., Stitt, A., Austin, P. C. (2012). Prediction of Heart Failure Mortality in Emergent Care. Annals of Internal Medicine, Vol. 156, No. 11, p. 767-775. Prieiga internete: http://www.ncbi.nlm.nih.gov/pubmed/22665814 [žiūrèta 2015-10-25].

Lietuvos Respublikos sveikatos apsaugos ministro 2008 m. sausio $16 \mathrm{~d}$. įsakymas Nr. V-39 „Dèl skubios konsultacinès sveikatos priežiūros pagalbos organizavimo ir apmokejjimo tvarkos aprašo patvirtinimo“. (2008). Valstybès žinios, Nr. 33-1190.

Lietuvos Respublikos Vyriausybès 2009 m. gruodžio 7 d. nutarimas Nr. 1654 „Dèl sveikatos priežiūros ịstaigų ir paslaugų restruktūrizavimo trečiojo etapo programos patvirtinimo“. (2009). Valstybès žinios, Nr. 150-6713.

Lietuvos Respublikos sveikatos apsaugos ministro $2010 \mathrm{~m}$. vasario $11 \mathrm{~d}$. įsakymas Nr. V-110 „Dèl pacientų siuntimo ị atitinkamo lygmens asmens sveikatos priežiūros ịstaigas dèl stacionarinių skubių ir planinių asmens sveikatos priežiūros paslaugų tvarkos aprašo patvirtinimo“. (2010). Valstybès žinios, Nr. 21-1010.

Lietuvos Respublikos sveikatos apsaugos ministro 2014 m. sausio 20 d. ịsakymas Nr. V-40 „Dèl üminio galvos smegenų insultų diagnostikos ir gydymo insultų gydymo centruose tvarkos aprašo patvirtinimo“. Teisès aktų registras, 2014-01-21, 2014-00358.

Lietuvos Respublikos sveikatos apsaugos ministro 2014 m. vasario 17 d. ịsakymas Nr. V-244 „Dèl sveikatos priežiūros paslaugų, teikiamų ūminio miokardo infarkto su ST segmento pakilimu atveju, prieinamumo gerinimo ir šia liga sergančių ligonių srautų valdymo reikalavimų patvirtinimo“. Teisès aktų registras, 2014-02-19, 2014-01758.

Lidal, B. I., Hilde, H. H., Gunn, E. V. (2013). Triage systems for pre-hospital emergency medical services - a systematic review. Scandinavian Journal of Trauma, Resuscitation and Emergency Medicine, Vol. 21, p. 28.

Ligtenberg, JM. J. (2005). Quality of interhospital transport of critically ill patient: a prospective audit. Critical Care. Prieiga internete: http://www.ccforum.com/content/9/4/R446 [žiūrèta 2015-10-25]. Meisler, R. (2010). Triage and mortality in 2875 consecutive trauma patients. Acta Anaesthesiologica Scandinavica, Vol. 54, Issue 2, p. 218-223.

Metinès GMP ataskaitos (2000-2014). Prieiga internete: <http://sic.hi.lt/spec_info/met_ata.ph.> [žiūrèta 2015-10-25].

Oakley, A. P. (1999). Interhospital transfer of the trauma patient. Trauma, Vol. 1, No. 1, p. 61-70.

Patient Access and Flow Health Service Directive. (2014). Guideline for Inter Hospital Transfers. Prieiga internete: https://www.health.qld.gov.au/directives/docs/gdl/qh-hsdgdl-025-3.pdf [žiürèta 2015-10-25].

Rehmani, R. (2004). Emergency Section and Overcrowding in a University Hospital of Karachi, Pakistan. Journal of Pakistan Medical Association, Vol. 54, No. 5, p. 233-236.

Robinson, K., Lystrup, A., Krohmer, J. et al. (2006). Guide for Interfacility Patient Transfer. National Highway Traffic Safety Administration. Prieiga internete: http://www.nhtsa.gov/people/injury/ems/Interfacility/images/Interfacility.pdf> [žiūrèta 2015-12-01].

Rourke, J., Kennard, M. (2001). Emergency patient transfers from rural hospitals: a regional study. Canadian Journal of Emergency Medicine, Vol. 3(4), p. 296-301.

Sampalis, J. S., et al. (1997). Direct transport to tertiary trauma centers versus transfer from lower level facilities: impact on mortality and morbidity among patients with major trauma. Journal of Trauma, Vol. 43, Issue 2, p. 288-296.

Santry, H. P., Velmahos, G. (2012). Interhospital Transfers of Acute Care Surgery Patients: Should Care for Nontraumatic Surgical Emergencies Be Regionalized? Reply. World Journal of Surgery, Vol. 36, p. 2945. 
Sayah, A., Rogers, L., Devarajan, K., Kingsley-Rocker, L., Lobon, L. F. (2014). Minimizing ED Waiting Time and Impruving Patient Flow and Experience of Care. Emergency Medicine International, Vol. 2014, Article ID 981472, p. 8.

Schoettker, P. et al. (2003). Reduction of time to definitive care in trauma patients: effectiveness of a new checklist system. Injury, International Journal of the Care of the Injured, Vol. 34, p. 187-190.

Skubios konsultacinés pagalbos veiklos apimtys 2009-2013 m. (2014). Valstybinè ligoniu kasa.

Van Lieshout, E. J., et al. (2008). Decision making in interhospital transport of critically ill patients: national questionnaire survey among critical care physicians. Intensive Care Medicine, Vol. 34, p. 1269-1273.

Lietuvos Respublikos sveikatos apsaugos ministerijos Ekstremalių sveikatai situacijų centras (LR SAM ESSC). (2015). Vieninga metodika sveikatos priežiūros įstaigoms, kaip organizuoti pagalba nukentẻjusiems nиo traumu ir kitu išoriniu mirties priežasčiu atvejais.

Verikienè, J., Jankauskienè, D. (2012). Pacientu ir sveikatos priežiūros paslaugu teikèju apklausos atlikimas ir analizés parengimas. Vilnius.

Warren, J., et al. (2004). Guidelines for the inter- and intrahospital transport of critically ill patients. American College of Critical Care Medicine, Vol. 32, No. 1, p. 256-262.

Whiteley, S. et al. (2011). The Intensive Care Society. Guidelines for the transport of the critically ill adult. 3rd Edition. Prieiga internete: $<$ http://www.ics.ac.uk/EasysiteWeb/getresource.axd?AssetID=482\& $>$ [žiūrèta 2015-12-01].

Wong, K., Levy. R. D. (2005). Interhospital transfers of patients with surgical emergencies: Areas for improvement. Australian Journal of Rural Health, Vol. 13, Issue 5, p. 290-294.

Zanco, M. (2014). Guideline for Inter Hospital Transfers. Patient Access and Flow Health Service Directive. Queensland Government. Prieiga internete: https://www.health.qld.gov.au/directives/docs/gdl/qh-hsdgdl-025-3. pdf [žiūrèta 2015-11-20].

\section{EMERGENCY MEDICAL ASSISTANCE: INTERHOSPITAL PATIENTY TRANSFER}

\section{Gintautas Virketis, Vinsas Janušonis, Vita Kvekšaitė}

\section{Summary}

The flow of interhospital patients transfer in many countries are increasing. The same situation in Lithuania. These changes of patients flow affect the accessibility and quality of health care. The interhospital patients transfer makes a great impact on human resources, technologies and planing of health care.

The problem, which is analysed in the article - what factors are currently the most relevant for interhospital patients transfer.

Object of research - opinion of medics and managers about management of interhospital patients transfer flow.

The aim of study - to explore and assess the opinijon of medics and managers of health care organizations about management of interhospital patients transfer flow and ways to improve them. 
Material and methods - the analysis of scientific literature, systematisation and comparison. A survey was carried out in hospitals and ambulance stations of Lithuania in 2015.

The study included 118 respondents - managers of hospitals, ambulance stations, departaments of emergency medical assistance.

Information was collected with special questionnare. Statistical data analyses was done using programme SPSS 21.

Results. In the study were analysed groups of problem: the long transfer time and delayed decision making (1), deflection of patients flow (2), regulations, rules and algorithms for interhospital transfer (3), patients transfer team (4) methods of transfer and patient monitoring (5) interhospital patients transfer results (6).

Discusses the management emergency medical patient flow against hospitalizations and between hospitals in Lithuania.

Conclusions. In the context of the centralisation of health care services is increasing the number of patients transported between hospitals.

The transport of patients in serious and critical condition carries the emergency assistance teams. Their departure time to call regulation can significantly reduce transportation time and accelerate the provision of qualified assistance.

University hospitals did not sufficiently prepared to accept growing flow of patients. Not all regional or district hospitals shall have the right to provide such assistance and, therefore, increases the time and cost spent for transportaion, this requires additional human resources.

The right organizing patients movement between secondary and tertiary care hospitals influenced on emergency medical availability and quality of services, reduce desparities and social exclusion.

The lack of data on patient transfers detailed patients flow analysis is not possible. 
